\title{
Minor Response in Neuroblastoma
}

National Cancer Institute

\section{Source}

National Cancer Institute. Minor Response in Neuroblastoma. NCI Thesaurus. Code C140669.

Partial response or complete response in at least one component (i.e., soft tissue, bone, and bone marrow disease) but at least one other component with stable disease; no component with prog ressive disease. (J Clin Oncol 35: 2580-2587, 2017) 